\title{
MEDICAL STAFF IN THE CARE OF A PREGNANT PATIENT DIAGNOSED WITH FETAL DEFECT
}

10.36740/WLek202101103

Weronika Dawid, Martyna Maciejewska, Inga Janik-Fuks, Dorota Ćwiek, Małgorzata Zimny, Olimpia Sipak-Szmigiel

DEPARTMENT OF OBSTETRICS AND PREGNANCY PATHOLOGY, POMERANIAN MEDICAL UNIVERSITY IN SZCZECIN, SZCZECIN, POLAND

\begin{abstract}
The aim: The research conducted aims at evaluating the way the medical staff functions in the care of the pregnant patient diagnosed with fetal defects.

Material and methods: 158 midwives took part in the study. The MINI-COPE standardized questionnaire and author's questions were used.

Results: During the period when the care was provided for the pregnant patients diagnosed with fetal defects, nearly $50 \%$ of the midwives under examination complained about the decline of their wellbeing. $75,3 \%$ of the respondents seek help and advice on how to deal with a stressful situation. Ideal for providing a systemic support, the midwives most often chose a psychologist and a psychotherapist. The surveyed who reported no need for a systemic support for the medical staff at the workplace, as the causes of their attitude pointed to their diminished trust in the ward nurse and no place for honest conversations. Most of the midwives surveyed during the care of the patient with the fetal defects experienced stress and bigger mental exhaustion. Over half of the surveyed reported lack of systemic psychological support provided for the medical staff at the workplace. Conclusions: The research indicates the need to introduce courses and training on topics related to how to deal with stressful situations into the education system of medical staff.
\end{abstract}

KEY WORDS: medical staff, prenatal care, obstetric nursing, fetal diseases, psychological stress

Wiad Lek. 2021;74(1):17-21

\section{INTRODUCTION}

The progress of medical science, including obstetrics, has set new tasks for medical personnel. This involves raising qualifications, gaining new powers and increasing independence of therapeutic team members. The incidence of abnormal course of pregnancies is increasing, which increases the challenges for a midwife, an obstetrician, but also the patient with diagnosed fetal defect. These pregnancies are subject to more frequent monitoring and are associated with the necessity of hospitalization at an earlier stage, caused by a child's state of health, a mother's or both. During a patient's pregnancy, an important role of a midwife is to ensure mutual communication and provide holistic care, which she initiates with her cooperation with a doctor, psychologist and family. A midwife should be characterized by sensitivity to the patient's problems, as well as efficiency in taking preventive actions and managing health problems [1].

The World Health Organization (WHO) defines congenital malformations as structural or functional abnormalities that occur in utero (intrauterine) and that are detected either in the prenatal period, at birth, or later, in early childhood [2]. The occurrence of birth defects in live-born children is estimated at $2-3 \%$. This number increases to $10 \%$ among stillborn births and up to $70 \%$ of miscarriages occurring in the early stages of pregnancy.

Genetic and environmental factors are recognized as the causes of birth defects. Differentiating birth defects in the fetus, we divide them into large (also lethal), with serious consequences for the health of the fetus, usually ending with medical interventions, and small ones. With the abovementioned defects, the number of deaths increases to infancy, as well as the need for hospitalization.

Thanks to the progress of medicine, development in obstetric and prenatal care, we have the possibility of early recognition of any disorders and defects. Changing the procedure for a patient with a diagnosed fetal defect is an immeasurable benefit. The standard of care also requires multidisciplinary cooperation in obstetric, nursing and medical teams. As a result, also cooperation with parents may change [3]. A number of decisions regarding the subsequent management of the child after delivery may involve extreme emotions in ethical and moral feelings. Unfavorable diagnosis disturbs a number of plans related to motherhood.

This situation poses challenges also for the medical staff $[4,5]$. The literature extensively describes and analyzes issues related to stress, burnout and excessive employee involvement. Facing health care personnel with the phenomenon of death causes a number of consequences, which is, among others deep sadness or a sense of loss. These reactions may be associated with helplessness and a greater need to show concern $[6,7]$. The specificity of work and tasks in the medical sector resulting from legal, organizational and ergonomic concepts affect workload. Working conditions affecting these concepts, such as time pressure, physical and mental effort (participation in human tragedies), employer support and the financial 
factor, show the danger of stress, post-traumatic stress and burnout among medical personnel [8-10].

Currently, the midwife's professional independence is gaining a new dimension. The particular risk of stress influences the psychophysical fitness of midwives; the consequence of which is health exposure, lower satisfaction and motivation from work [11-13]. The possibility of vocational education raising the qualifications of midwives, as well as greater professional awareness, does not blur the customs and traditions in the specificity of work performed and does not comply with applicable care standards $[8,11]$. The remuneration system does not compensate for work in the profession of a midwife in which contact with the patient is dynamic, characterized by specific principles of creating a sense of trust [11]. The implementation of professional tasks and lack of support from superiors, the therapeutic team they work with, employers and the society increase the degree of workload [10,14-16]

In the literature, "coping with stress" appeared in the sixties [17]. Stress affects the mental regulation system, which is why the process of coping with stress is important. It is necessary to maintain human behavioral and mental balance $[17,18]$.

The midwife's work is particularly burdened for reasons of participating in surgical deliveries, including termination of pregnancy, work with people with emotional load, or because of moral doubts. It can result in a lack of job satisfaction, or even stress conducive to burnout [19]. Increasingly, you can come across the problem of court cases, where the accused are midwives and / or obstetrician [20].

That is why the support we can get from the self-help group turns out to be so important. Medical workers get the greatest support related to stress at work in the bio-psychic renewal group, where awareness and self-knowledge are expanded. A consultant in such a group is a clinical psychologist [17].

\section{THE AIM}

The main objective of the study was to assess the functioning of midwives in caring for a patient with a diagnosed fetal defect.

\section{Research issues:}

1. Analysis of systematic and related to psychological experiences support received by midwives in the care of a patient in whom a fetal defect was found.

2. Assessment of the influence of midwives' sociodemographic factors in caring for a patient with a fetal defect.

3. Assessment of stress management strategies in midwives in the care of a patient with a fetal defect.

\section{MATERIAL AND METHODS}

The research was conducted in the period from October 2018 until March 2019; 158 women took part in it. The selection for the group was random. The respondents were informed that the survey is completely voluntary and anonymous, and the results obtained will be used for scientific purposes. The material was collected by means of a diagnostic survey, survey technique, using the standardized MINI-COPE questionnaire. The survey consisted of 40 questions. The first part contained the sociodemographic characteristics of the respondents, the second part was the Mini-COPE questionnaire, while the third part of the survey consisted of author's questions.

The COPE Inventory is used for measurement of Coping with Stress. It contains 28 statements included in 14 strategies (2 statements in each strategy), which are: active coping, planning, positive re-evaluation, acceptance, sense of humor, turning to religion, seeking emotional support, seeking instrumental support, doing something different, denying, discharging, taking psychoactive substances, stopping actions, blaming oneself.

\section{RESULTS}

The significance of differences was determined by carrying out the Kruskal-Wallis test for independent groups. The Pearson chi square test was used to assess dependencies in surveys. Statistical analysis was performed using Statistica v 10.0 Statsoft, assuming a 5\% probability of error.

The sociodemographic analysis concerned age, education and seniority of the respondents. The majority of midwives surveyed $-44.3 \%$ were in the age group up to 30 years of age, another $41.8 \%$ were midwives in the 31-55 age range, while the least $13.9 \%$ of the surveyed were over 51 years old. Among the respondents, $39.9 \%$ of midwives had a master's degree or specialist, $33.5 \%$ completed medical study of midwifery or bachelor's degree, while $26.6 \%$ of midwives holding a bachelor's or master's degree had an additional specialization. The largest group were midwives with up to 5 years of seniority $-40.5 \%$, while the smallest with $11-20$ years of experience $-15.8 \%$. The vast majority of midwives surveyed $-65.2 \%$ worked in hospitals with the 3 rd degree of reference.

The analysis of the responses to the questions contained in the author's questionnaire is presented in Table 1.

Analyzing the relationship between work experience and the experience of stress during the care of a patient with a fetal defect, a statistically significant difference was found $(p=0.014440)$. Most often, stress in such a situation is experienced by midwives working for 5 years ( $91 \%$ of this group). There is also a statistically significant relationship $(\mathrm{p}=0.005834)$ between work experience and participation in courses or training aimed at coping with difficult situations in the ward; midwives working for over 20 years most often participated in such courses. The analysis showed that there is also a statistically significant relationship ( $p$ $=0.001081$ ) between work experience and the knowledge of the functioning of systemic psychological support for medical personnel. The most aware of the lack of such support are midwives working for up to 5 years; women with 11-20 years of work experience most often do not know if such support exists in their workplace. 
Table 1. Responses given by the respondents in the author's questionnaire.

\begin{tabular}{|c|c|c|c|}
\hline \multirow[t]{2}{*}{ Questions contained in the questionnaire } & \multicolumn{3}{|c|}{$\begin{array}{l}\text { Responses given by the respondents } \\
\text { (in percent) }\end{array}$} \\
\hline & Yes & No & I do not know \\
\hline $\begin{array}{l}\text { When looking after a patient with a diagnosed fetal defect, do you experience } \\
\text { greater mental fatigue than usual? }\end{array}$ & 80 & 15 & 5 \\
\hline $\begin{array}{l}\text { When looking after a patient with a diagnosed fetal defect, do you experience } \\
\text { deterioration of physical well-being? }\end{array}$ & 47 & 39 & 14 \\
\hline Do you feel stress while taking care of a patient with a diagnosed fetal defect? & 81 & 15 & 4 \\
\hline $\begin{array}{l}\text { Did you participate in courses / trainings that were aimed at dealing with difficult } \\
\text { situations in the ward? }\end{array}$ & 32 & 68 & - \\
\hline Does your workplace have systemic psychological support for medical staff? & 18 & 64 & 18 \\
\hline Should there be systemic support for medical personnel? & 95 & 1 & 4 \\
\hline
\end{tabular}

Source: own study.
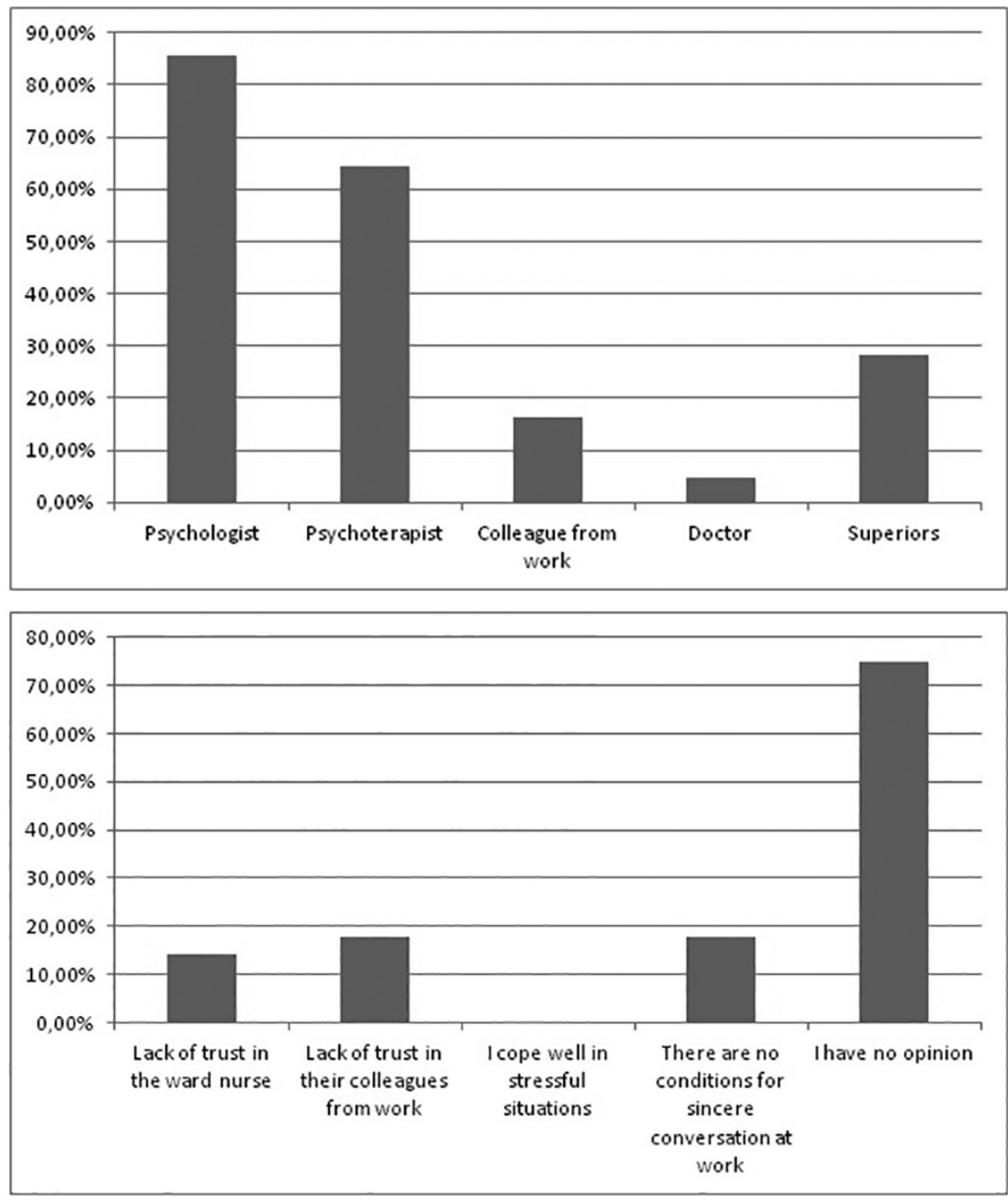

Fig. 1. A list of people ideal for providing systemic support to medical personnel.

Source: own study.

Fig. 2. A list of reasons for the lack of willingness among midwife respondents for the functioning of systemic support for medical staff in the workplace.

Source: own study.
In response to the question about the desire to receive systemic support in the workplace, the midwives indicated persons who would ideally provide such support. The most frequently mentioned mentors $-85.5 \%$, psychotherapist $-64.5 \%$, supervisor $-28.3 \%$. In turn, $16.4 \%$ of the respondents considered their colleague from work and $4.6 \%$ - the doctor, as persons suitable for providing support (Fig. 1).
$17.9 \%$ of midwives, as a reason for the lack of willingness to have systemic support for medical personnel operated in the workplace, stated lack of trust in their colleagues and recognized that there are no conditions for honest conversation at work. $14.3 \%$ of respondents as the reason stated lack of trust in the ward nurse (Fig.2). 
The most important information obtained thanks to the analysis of the results of the MINI-COPE questionnaire is presented below:

1. A positive phenomenon was observed, which was avoidance of stimulants. The vast majority of midwives surveyed $-72.2 \%$ showed that they almost never took alcohol or other drugs to feel better in a stressful situation. It is satisfactory that none of the respondents indicated the answer "almost always" and that only 6.3\% of respondents often chose these stimulants.

2. In the case of achieving the intended goal, the examined midwives rarely $-46.2 \%$ or almost never $-39.9 \%$ gave up attempts to achieve it.

3. The vast majority of the surveyed women $-75.3 \%$ seek advice and help from others regarding to what should be done, $19.6 \%$ of midwives almost always developed such a strategy or plan of action for coping with stress. Only $4.4 \%$ of respondents did so rarely or almost never $-0.6 \%$.

4. Another way to deal with stress, was to seek solace in their faith. The responses of the midwives surveyed were very diverse: $34.8 \%$ of women almost never chose such a way, rarely $-29.1 \%$, often $-24.1 \%$ and nearly always $-12.0 \%$.

\section{DISCUSSION}

Based on our own results, it was found that while caring for a patient with a diagnosed fetal defect, almost half of the midwives surveyed declared a deterioration in physical well-being. Nowakowska et al. [21] in her research presents similar results. $39 \%$ of nurses participating in the survey complain of physical exhaustion during work. The analysis of own research showed that $63.9 \%$ of midwives do not have systemic support for medical workers in the workplace. This was also confirmed by the research of Saiful-Islam et al. [22] conducted in nursing homes in Great Britain. The presented research showed that employees of primary health care in difficult situations could not count on the support of superiors. The vast majority of respondents, as much as $79.9 \%$, declared greater mental fatigue. Similar results were obtained by Nowakowska et al. [21], in which $65 \%$ of nurses declared their work as emotionally exhausting. In the Mróz [23] study, emotional tension is consistent with the overloaded type, and negative correlation in functioning with unambitious type.

The author compares her research with the results of Golińska, in which different correlations were observed. In the theory of work-related behaviors and experiences, Maslach notes the relationship between feeling of stress and burnout, in which she details emotional exhaustion [23].

At the same time, our own research has noted that there is a very high demand for systemic support for medical personnel. As much as $96 \%$ of respondents indicate the essence of implementing such support. Similar observations were made by Banasiewicz [19], where $56 \%$ of midwives report lack of professional support.

Comparable results were obtained by Kluczek et al. [24], in which $3 / 4$ respondents also noticed the need to introduce employee training in dealing with difficult situations. The same study group assessed that such a support system would stop using defense mechanisms to alleviate negative experiences.

\section{CONCLUSIONS}

The conclusions can be summarized as follows:

1. Most midwives surveyed experienced stress while caring for a patient with a diagnosed fetal defect.

2. Most midwives do not have systemic psychological support for medical personnel in the workplace, and some respondents do not know whether they can receive such systemic support.

3. The education of midwives and the hospital's reference level did not affect the way of coping with stress.

4. Most of the respondents did not participate in courses or training that would be aimed at dealing with difficult situations in the ward.

This research indicates the need to introduce courses and training on topics related to coping with stressful situations into the medical staff training system. Difficult situations in which medical staff meets the suffering and sadness of the patient, burden the mental health of the employees. At the same time, access to systemic support is still insufficient. The information about the lack of trust towards colleagues or superiors at work is disturbing - and the resulting lack of systemic support. Based on the current literature, the scientific community agrees that psychological and emotional support is one of the basic conditions for good management and work organization. Therefore, it is important to realize the need to organize such support in order to improve the quality of work of the ward staff, the quality of services provided, and to obtain job satisfaction.

\section{REFERENCES}

1. Iwanowicz-Palus G, Krysa J, Bień A. Rola położnej rodzinnej w Polsce. Med Ogól Nauki Zdr. 2013;19(3):272-278.

2. Rutkowska M, Szczepaniak S. Postępowanie paliatywne w opiece perinatalnej. Warszawa: Wydaw. Lekarskie PZWL, 2018.

3. Szmyd K, KrzeszowiakJ, Śmigiel R. Wady letalne u płodówi noworodków z punktu widzenia medycyny paliatywnej i hospicjum perinatalnego. Prz Pediatr. 2016;(3):28-34.

4. Stadnicka S, Bień A, Gdańska P, Piechowska J. Poronienie i ciąża obumarła w aspekcie prawa - udział położnej w opiece nad pacjentką w sytuacji utraty ciąży. J Educ Health Sport. 2016;6(9):379-390.

5. Kornas-Biela D. Niepomyślna diagnoza prenatalna: dylemat rodziców, wyzwanie dla profesjonalistów. Med Prakt Ginekol Położ. 2008;(4):15-27.

6. Fopka-Kowalczyk M. Poczucie straty po śmierci pacjenta doświadczane przez pracowników opieki paliatywnej. Badania jakościowe. Med Paliat Prakt. 2014;8(1):23-28.

7. Roskoden FC, Kruger J, Vogt LJ, Gartner S, Hannich HJ, Steveling A, et al. Physical Activity, Energy Expenditure, Nutritional Habits, Quality of Sleep and Stress Levels in Shift-Working Health Care Personnel. PLoS One. 2017;12(1). doi: 10.1371/journal.pone.0169983.

8. RachwałM, WójtowiczS, BanasiewiczJ, RozenekH. Obciążenia związane z pracą a zaangażowanie w pracę i wypalenie zawodowe położnych. Położ Nauka Prakt. 2016;(4):26-31. 
9. Meng R, Li J, Zhang Y, Yong Y, Luo Y, Liu X, et al. Evaluation of Patient and Medical Staff Satisfaction regarding Healthcare Services in Wuhan. Public Health. 2018;15(4):769. doi: 10.3390 / ijerph15040769.

10. Rogala-Pawelczyk G. Obciążenie pracą na stanowisku położnej i pielęgniarki. Mag Pielęg Położ. 2013;(1/2):38-39.

11. Mollart L, Skinner V, Newing C, Foureur M. Factors that may influence midwives work - related stress and burnout. Women and Birth. 2013;26(1):26-32.

12. Stachulska A, Bąk-Sosnowska M, Gruszczyńska M. Kontrola emocji oraz poczucie własnej skuteczności w grupie położnych. Położ Nauka Prakt. 2013;(2):14-18.

13. Sochocka L, Wojtyłko A, Grad I, Kiliś-Pstrusińska K. Spostrzeganie stresu zawodowego przez pracowników ochrony zdrowia. Fam Med Prim Care Rev. 2012;14(2):219-221.

14. Gruszczyńska M, Skowrońska E, Bator A, Bąk-Sosnowska M. Staż pracy, poziom wypalenia zawodowego i strategie radzenia sobie ze stresem wśród położnych. Med Ogól Nauki Zdr. 2014;20(3):276-281.

15. AnskarE, Lindberg M, FalkM, Andersson A. Time utilization and perceived psychosocial work environment among staff in Swedish primary care settings. BMC Health Serv Res 2018;(18):166. doi: 10.1186/s12913018-2948-6.

16. Mroczkowska D.Wpływ sumienności isposobów radzenia sobie w sytuacjach stresowych na jakość życia. Hyg Pub Health. 2013;48(2):205-210.

17. Heszen I, Sęk H. Zdrowie i stres w Psychologia. Podręcznik akademicki. vol.2. Gdańsk: Gdańskie Wydawnictwo Psychologiczne, 2016.

18. Bańkowska A. Stress and occupational stress - selected theoretical contexts. Pielęg Pol. 2016;(4):584-587.

19. Banasiewicz J, Rozenek H, Wójtowicz S, Pawłowski W. Wybrane cechy środowiska pracy a wypalenie zawodowe położnych uczestniczących w zabiegach przerywania ciąży. J Educ Health Sport. 2017;(7):270-288.

20. Cekański A, Łosik M. Próba ujednolicenia postępowania wyjaśniającego przyczyny zgonu lub ciężkiego stanu dziecka w zaawansowanej ciąży i podczas porodu. Ginekol Dypl. 2012;14(3):42-47.

21. Nowakowska I, Rasińska R, Roszak K, Bańkowska A. Pielęgniarstwo zawód szczególnie narażony na stres i wypalenie. Wybrane założenia teoretyczne i wstępne doniesienie z badań. Pielęg Pol. 2017;(1):120-124.

22. Islam MS, BakerC, Huxley P, Russell IT,Dennis MS. The nature, characteristics and associations of care home staff stress and wellbeing: a national survey. BMC Nurs. 2017;(16):22. doi: 10.1186/s12912-017-0216-4.
23. Mróz J. Prężność i poczucie stresu a typy zachowań i przeżyć związanych z pracą wśród pielęgniarek. Hyg Pub Health. 2014;49(4):857-863.

24. Kluczek I, Krupienicz A. Reakcje emocjonalne pielęgniarek z powodu śmierci pacjenta i sposoby redukcji doświadczanego stresu na podstawie badań własnych. W drodze do brzegu życia. vol. 4. Białystok; 2008, pp.307-315.

\section{ORCID and contributionship}

Weronika Dawid - 0000-0001-8800-0467 ${ }^{A, B, C}$

Martyna Maciejewska - 0000-0002-2017-5196 D, F

Inga Janik-Fuks - 0000-0002-4238-0465 C, B,D

Dorota Ćwiek - 0000-0002-4908-9056 E, F

Małgorzata Zimny - 0000-0003-1695-6966 C,E

Olimpia Krystyna Sipak-Szmigiel-0000-0002-3410-1809 A, E, F

\section{Conflict of interest}

The Authors declare no conflict of interest

\section{CORRESPONDING AUTHOR}

Olimpia Krystyna Sipak-Szmigiel

Department of Obstetrics and Pregnancy Pathology,

Pomeranian Medical University in Szczecin,

48 Żołnierska st., 71-210 Szczecin, Poland

tel: 608072007

e-mail: olimpiasipak-szmigiel@wp.pl

Received: 19.10 .2020

Accepted: 29.12 .2020

A - Work concept and design, B - Data collection and analysis, C - Responsibility for statistical analysis, D-Writing the article, $\mathbf{E}$-Critical review, $\mathbf{F}$ - Final approval of the article 